\title{
Analysis of Management Systems and Trader's Behavior in Managing Waste at Kamulan Market, Durenan District, Trenggalek Regency
}

\author{
Agista Windanastiti ${ }^{1}$, Supriyadi Supriyadi ${ }^{2}$, Agung Kurniawan ${ }^{3 *}$ \\ ${ }^{1,3}$ Department of Public Health, Faculty of Sport Science, Universitas Negeri Malang, Malang, East Java, Indonesia \\ ${ }^{2}$ Department of Sport Science, Faculty of Sport Science, Universitas Negeri Malang, Malang, East Java, Indonesia \\ *Corresponding author. Email: agungkurniawan.fik@um.ac.id
}

\begin{abstract}
The purpose of this study is to obtain an overview of the waste management system applied in Kamulan Market and a description of the behavior of traders in managing waste. This study uses a descriptive survey method with a case study design. While the approach used is a qualitative approach. The targets of this research are market residents who are considered to know about the market situation including market coordinators, cleaners, and market traders. Targeting is done by purposive sampling technique. The results of the research show that the overall trash management activities carried out in Kamulan Market have not been in accordance with the provisions. The discrepancy lies in the activities of sorting and processing trash. In addition, regulations regarding trash management and market cleanliness are still not running optimally. The traders have carried out their obligations by paying dues to market managers as their responsibility to maintain cleanliness. Nevertheless, there are traders who do not maintain the cleanliness and leave it at a fish are rubbish its on-site selling.
\end{abstract}

Keywords: market trash, trash management, trader's behavior

\section{INTRODUCTION}

Environmental problems are closely related to human activities. Humans carry out various activities to meet the welfare of their lives and of course produce waste material called garbage. Garbage is a material that is wasted or intentionally disposed of which is the result of human or natural activities that is no longer used because its main element or function has been taken [1]. The problem of waste in Indonesia is a complicated problem because of the lack of public understanding of the consequences caused by waste and the minimal cost given by the government to seek proper and qualified waste disposal. In addition, it is coupled with the increasing standard of living of the community, which is not accompanied by a harmony of knowledge and also the lack of community participation in maintaining cleanliness [2].

Garbage is found in public places. The interaction in public places allows disease to occur if it is not supported by good environmental conditions and good sanitation. So that public places must meet health requirements in the sense of protecting, maintaining, and enhancing the degree of public health [3]. The market is one of the public places that is a source of meeting the daily needs of the community. The problem of traditional market waste is one of the most complicated waste problems. Existing activities, both buying and selling from traders to consumers, will indirectly lead to piles of garbage and make the market environment dirty and smelly [4]. Market waste has distinctive characteristics, large volume, high water content, and easy to decompose [5]. Poor market waste management system and deviant behavior will have a negative impact on health and reduce environmental quality. A study describes an example of due to poor waste management at the Sungguminasa Central Market, piles of garbage in the market have soared and cause air pollution such as unpleasant odors and disruption of vehicle traffic around the market [6].

Market waste management is inseparable from the waste management system and also the role of market traders, where in the process there are still waste management behaviors that are not in accordance with the provisions. A study at the Caringin Main market in Bandung showed the results that the waste management 
system carried out was still not carried out optimally, this could be seen from the condition of existence that there were still many problems, especially the waste operational system in the market [7]. While the research results Mentari, Suasti, \& Syahar (2018) regarding the participation of traders in waste management in the Bawah market, Bukittinggi City, it shows that the behavior of waste management by traders is still lacking, most of the traders provide their participation in the form of material, namely paying a waste retribution [8].

Problems related to market waste management are complex. In order not to cause problems for health and the environment, systematic and sustainable management is needed in accordance with the rules that have been set. The provisions for waste management have been regulated in the RI Law Number 18 of 2008 concerning waste management [9]. The waste management system does not only concern waste management activities, but also relates to management, policies and regulations, infrastructure, retribution fees, and existing information and appeals. Apart from being systematic and sustainable, the waste management system must also be supported by the participation of traders. The role of traders in market waste management can be realized in the form of direct or indirect involvement which includes: providing trash cans, efforts made by traders to maintain cleanliness, efforts to reduce and reuse waste, as well as cleaning retribution fees.

Kamulan Market is a market located in Durenan District, Trenggalek Regency and is included in the branch market category with an area of $\pm 1,600 \mathrm{~m} 2$. This market has just finished being updated and repaired at the end of 2019. At Kamulan Market there are 30 main stalls outside the market and there are 288 traders with different types of merchandise. Currently, the problem in Kamulan Market is that the market environment looks dirty because of scattered garbage. In addition, the use of TPS in Kamulan Market is not functioning properly, even though the TPS location is very narrow with a size of $3 \mathrm{x}$ 4 meters and is \pm 3 meters from the merchant area. Market waste management system is not an easy thing to do. However, a good and systematic waste management system is needed, both from management management and the participation of traders in managing waste. The intended role is the treatment of waste before it is disposed of and the provision of garbage bins. Based on the above background, the researchers are interested in conducting research on "Analysis of Management Systems and Trader Behavior in Managing Waste at Kamulan Market, Durenan District, Trenggalek Regency".

\section{METHOD}

This study uses a descriptive survey method with a case study design. While the approach used is a qualitative approach. The targets of this research are all market residents who are considered to know about the market situation, especially regarding waste management, including market coordinators, cleaners, and market traders. The selection of market traders is done by considering the length of time they have been selling, what kind of waste they produce, their willingness to be interviewed, and the weight of the answers.

The research was conducted from February 2021 to March 2021 at Kamulan Market which is located on Jl. Raya Kamulan - Durenan, Kamulan Village, Durenan District, Trenggalek Regency, East Java. The type of data used consists of primary data and secondary data. Primary data are the results of in-depth interviews with sources, observations, and documentation, while secondary data are data obtained from archives, written reports, documents, and journals related to the problems studied. In this study, the selection of data sources was carried out through two stages, that is:

a. Purposive Sampling technique is a technique used in taking the object of research if the researcher has certain considerations. In this study, the researcher chose the Head of the Market Unit or the market coordinator as the key informant.

b. To complete the required data, the Snowball Sampling technique is also used, namely seeking information from those recommended by key informants so that the data obtained can be valid and complete. In this case the cleaners who work directly in the field and market traders.

Data collection techniques used to complete data according to research needs were also carried out by means of library research, direct observation, structured interviews and document research. The instruments used in this research include: human instrument, observation guide, interview guide, and recording device (image and sound). Testing the validity of the data is done by triangulation technique. Triangulation as a combination or combination of various methods used to examine interrelated phenomena from different perspectives and perspectives [10]. While the data analysis technique carried out in this study refers to the concept of Miles and Huberman where the data analysis process is divided into 3 , including data reduction, data presentation, and drawing conclusions [11].

\section{RESULTS}

This study examines the waste management system and the behavior of traders in managing waste by taking the location at Kamulan Market. Kamulan Market is a meeting place between sellers and buyers which is located in Durenan District, Trenggalek Regency and is included in the branch market category with a market location area of $\pm 1,600 \mathrm{~m} 2$. This market has just finished being updated and repaired at the end of 2019. At 
Kamulan Market there are 30 main stalls outside the market and there are \pm 288 traders with different types of merchandise. The strategic location of the market on the edge of the highway makes it easy for people to reach the market.

To expedite the activities of the market system, Kamulan Market is equipped with 5 market managers. The task of the market manager is to ensure that the market system runs well, and also acts as a salary and collects market retribution. In addition to market managers at Kamulan Market, there are also janitors and market traders who are responsible for market cleanliness.

Table 1. Characteristics of Informants

\begin{tabular}{|c|l|l|l|l|}
\hline No. & Name & Age & $\begin{array}{l}\text { Last } \\
\text { education }\end{array}$ & $\begin{array}{l}\text { Occupation/ } \\
\text { Position/ } \\
\text { Type of } \\
\text { Business }\end{array}$ \\
\hline 1. & Informant 1 & 52 & STM & $\begin{array}{l}\text { Kamulan } \\
\text { Market } \\
\text { Coordinator/ } \\
\text { Market } \\
\text { Manager }\end{array}$ \\
\hline 2. & Informant 2 & 29 & SMK & Janitor \\
\hline 3. & Informant 3 & 29 & SMA & $\begin{array}{l}\text { Vegetable } \\
\text { seller }\end{array}$ \\
\hline 4. & Informant 4 & 43 & SMA & Fish seller \\
\hline 5. & Informant 5 & 61 & SD & $\begin{array}{l}\text { Vegetable } \\
\text { seller }\end{array}$ \\
\hline 6. & Informant 6 & 51 & SD & Fruit Trader \\
\hline 7. & Informant 7 & 41 & SMA & Fruit Trader \\
\hline & & & & \\
\hline
\end{tabular}

\subsection{Waste Management System at Kamulan Market}

The waste management system does not only concern waste management activities, but also relates to management, policies and regulations, infrastructure, user fees, and existing information and advice.

\subsubsection{Waste Management at Kamulan Market}

To expedite market waste management activities, Kamulan Market is equipped with 5 market managers, namely Mr. Ruslan as market coordinator, then there are Salar officers Ruri, Sayuti, Agus Setiawan, and Parman. In addition to the market manager at Kamulan Market, there are also three cleaners who are responsible for the cleanliness of the market, traders and pesavon who sweep the Kamulan Market environment. Based on data obtained from resource persons related to waste management, the person responsible for cleanliness and waste management at Kamulan Market is the coordinator of Kamulan Market, namely Mr. Ruslan. As the person in charge, he must mobilize and direct all market residents so that the waste management and management system can run well. However, in the process of implementing waste management and market cleanliness, it is the responsibility of the cleaners. As stated by the following informant:
"Yes, I am in charge. Same name Desta, nickname Rio, that's the executor of the cleaning. But the one in charge of me."

\section{(Kamulan Market Manager/Market Coordinator)}

"Usually there are 3 people, including me. But the one responsible is still the market manager."

(Kamulan Market Cleaning Officer)

\subsubsection{Policies and Regulations Regarding Cleanliness and Waste Management}

The waste management process at Kamulan Market is based on Trenggalek Regency Regulation Number 27 of 2016 concerning waste management article 7 paragraph (1) [12]. With regulations related to waste management, it is hoped that the community will be orderly and disciplined in maintaining the cleanliness of the market. However, in reality, there are no written regulations in Kamulan Market regarding cleanliness and waste management. Market managers only campaign and invite traders to always maintain cleanliness and manage their waste properly. As stated by the following informant:

"Yes, we follow district regulations. Not the cleanliness of the market, but the management of the waste. In the market itself, there are no written/special regulations. Just tell the merchant to keep it clean."

(Market Manager/Market Coordinator)

In connection with the narrative of the market manager, the researcher also interviewed traders as the people who produce market waste. He gave answers regarding the existing regulations in the Kamulan Market, as follows :

"Nothing, I just told them the instructions, when they finished selling, they were told to clean up. Later if you don't clean it, you will be given another warning".

(Trader 1)

There was never a rule, just let it go. Just being told about the trash can, the important thing is that it has been swept separately".

(Trader 2)

\subsubsection{Waste Management Activities at Kamulan Market}

Waste management activities according to Law of the Republic of Indonesia Number 18 of 2008 concerning Waste Management and also Government Regulation of the Republic of Indonesia Number 81 of 2012 concerning 
Management of Household Waste and Waste Similar to Household Waste [9], [13], can be described as follows:

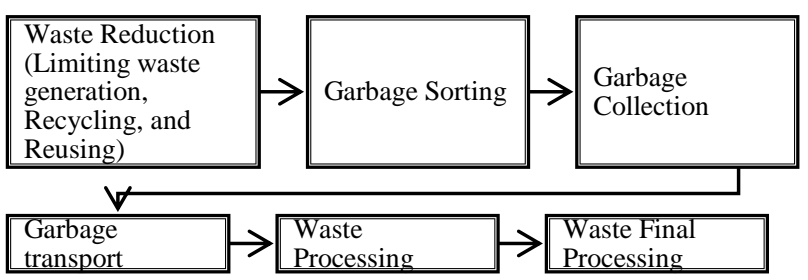

Figure 1. Flow of Waste Management Activities according to the Law of the Republic of Indonesia Number 18 of 2008 and Government Regulation of the Republic of Indonesia Number 81 of 2012

The first, is the reuse of waste. Waste reduction efforts carried out at Kamulan Market are by reusing the generated waste. These activities are carried out by market traders. From the data obtained by researchers after interviews and observations, efforts to reduce waste by traders are reusing leftover waste from selling for animal feed in the form of vegetables that are not worth selling, fruit peels, and other wet waste. If it is possible to sell it, they will sell it as fodder to anyone in need. However, if the waste is no longer suitable for reuse, they will just throw it away.

Second, sorting garbage. Waste handling efforts carried out at Kamulan Market start from the waste sorting process. Based on the results of interviews with market managers and market cleaners, in Kamulan Market there is no separate trash can between organic and inorganic waste. The waste is put together and then later it will be sorted by the cleaning staff between plastic waste that can be sold and those that cannot be reused. Based on the results of observations made by researchers, there is no separate trash can at Kamulan Market. The sorting is done after the waste is collected, and even then only for waste that can indeed be sold. The following is the informant's statement regarding waste sorting and providing separate trash bins:

"Nothing, still one. No one has done the waste sorting yet. At most someone will clean it later alone"

\section{(Market Manager/Market Coordinator)}

Third, garbage collection. The process of collecting waste is carried out by market traders and also cleaners. Market waste that has been collected by traders and cleaners is then temporarily collected at the market TPS. Based on the results of observations, researchers observed the activities of traders when collecting their waste after selling, some were collecting their waste into plastic, into buckets, into fruit racks, immediately thrown into the market trash can, and some were only collected so that they could be swept away by cleaners. . After the traders' waste is collected, the janitor collects the garbage from the merchant's place and puts it into used sacks to facilitate the process of transporting waste The waste will be temporarily stored in the market TPS.
Kamulan market polling stations are located inside Kamulan Market with a distance of \pm 3 meters from TPS to traders. Kamulan Market has a size of $3 \times 4$ meters which can accommodate market waste for 3 days, after more than 3 days the TPS will be full and will cause environmental problems, namely an unpleasant odor. Given the location of the TPS which is so close to the traders and the narrow location, the waste must be transported every day. As stated by the following informant:

"Closed, there are walls, roofs and doors with a distance of 3 meters to the merchant. So far, it is rarely accommodated there. Moreover, if there used to be disposal, it was never accommodated and immediately disposed of. If you can accommodate it for 3 days, you can, but rarely. At most 3 days still able but smells like."

(Market Manager/Market Coordinator)

Fourth, waste transportation. After the market waste is collected, the Kamulan Market waste will be transported to the TPS. Then carried out the transfer and transportation to the final disposal site. Based on the data obtained by the researchers after interviews and observations showed that the efforts to transport the waste of traders were carried out every day by the cleaners. The traders' waste is carried out after the buying and selling activities are completed between 12.00 and 15.00. The means of transportation is a garbage cart. Meanwhile, the transportation of waste to the final disposal site uses a 3-wheeled motorbike every 2 days.

Fifth, waste management. The majority of the waste produced by the market is organic waste. Organic waste in general can be used for many things such as fertilizer, bio gas, animal feed, if processed properly. However, based on the results of observations and observations at the Kamulan Market, there is no waste processing yet. From the results of interviews, it was found that in Kamulan Market there is no waste processing because the place is too narrow and not adequate. As stated by the following informant:

"Not yet, in the past, it was proposed to be processed into fertilizer. But it failed, because the place does not exist. Kamulan Village is not ready to give place"

(Market Manager/Market Coordinator)

The six, final processing of waste. The final processing of market waste is carried out after a temporary storage process at the TPS for 1-2 days or a maximum of 3 days, then the waste is transported using 3-wheeled waste carriers to be taken to the disposal site. Kamulan Market waste was once made a dumping ground in Kamulan Village because the market location is far from the final waste disposal site in Trenggalek Regency. Considering the location of the Kamulan 
Market which is in the border area of the district and Kamulan Village, including a densely populated village, some residents have protested against the existence of the disposal site because the disposal site causes the environment to become dirty and not beautiful. So the waste disposal of Kamulan Market was finally diverted to Durenan disposal. The following is an excerpt from the market manager's statement regarding the final processing of waste at Kamulan Market:

"In the past, the waste was managed (discarded) here by renting a place, but now there is nothing to rent. Because residents protested not to throw garbage around here. Finally it was transferred to Durenan at the garbage dump and immediately transported by truck."

(Market Manager/Market Coordinator)

\subsubsection{Waste Management Facilities and Infrastructure at Kamulan Market}

Based on observations made by researchers at Kamulan Market on March 2, 2021, there are facilities in the form of cleaning tools such as brooms, cikrak, trash cans, hoes, and sickles. In addition to cleaning equipment, the Kamulan Market also provides waste transportation equipment in the form of garbage carts and 3 wheel motors. Meanwhile, the waste management infrastructure provided by the market is the location of TPS and market buildings. Infrastructure facilities in Kamulan Market can be seen from the results of the documentation carried out by researchers.

At Kamulan Market, trash cans have been provided at several market locations specifically for traders, but the trash cans are not given to each trader because the amount is so minimal. The following researchers describe the results of the market manager's narrative:

"Public trash cans are provided for traders. There are many, but not every merchant is given a trash can. I also provide (cleaning tools), including brooms, chips, hoes."

(Market Manager/Market Coordinator)

\subsubsection{Fee for Cleanliness}

All traders who sell at Kamulan Market are required to pay a levy fee of Rp. 2000 for tax and market cleaning purposes, such as buying cleaning equipment, paying pesafon salaries, and others. Withdrawal of these fees uses a ticket which is carried out by the Salar officer every day to all traders. The results of observations made by researchers indicate that the activity of withdrawing retribution is carried out in the morning between 07.0009.00 hours by market officers. The following is an explanation of market managers regarding levy fees and their uses:
"There is a fee of 2000 per trader for space and cleanliness. The levy fee is used to pay for cleaning staff, procurement of cleaning equipment, and transportation."

(Market Manager/Market Coordinator)

\subsubsection{Information and Appeals to Maintain Cleanliness}

Market cleanliness is a shared responsibility, both market managers and market traders must work together to create a healthy, clean and comfortable market. It is also important to provide information and advice so that there is no negligence in carrying out duties and obligations. In addition, market managers, janitors, and agencies also need to increase socialization regarding the importance of maintaining market cleanliness to market residents and the general public, especially information about the importance of sorting wet and dry waste. It is also necessary to impose sanctions on people who are found to have violated regulations in order to create good waste management.

"If there is an appeal, it will be in the form of verbal not written. Usually we give that warning at the time of ticket withdrawal to traders. We tell traders to always keep the market clean, don't forget to clean the trash, don't throw garbage carelessly."

(Market Manager/Market Coordinator)

\subsection{The Behavior and Role of Kamulan Market Traders in Waste Management}

The role of traders in market waste management can be realized in the form of (a.) Provision of trash cans, (b.) Efforts made by traders to maintain cleanliness, (c.) Efforts to reduce and reuse waste, (d.) Cleanliness retribution fees.

\subsubsection{Provision of Trash}

Most of the traders in Kamulan Market do not have a special trash can at their place of sale. However, some of them stated that they had temporary and makeshift trash cans to store their waste before throwing it into the trash can provided by the market manager. Traders temporarily store their waste in plastic bags/cracks, buckets/dippers, fruit baskets/fruit boxes. As stated by the following informant:

"Well, it's just collected, sis, if not, then put this fruit box if there's a lot of garbage.

(Trader 2)

"Throw it away, sis, put it in a garbage bucket like that.

(Trader 3) 


\subsubsection{Efforts Made by Merchants to Maintain Cleanliness}

In general, the efforts made by traders at Kamulan Market to maintain cleanliness are that traders collect the remaining waste from selling, besides that they also clean the place of sale by sweeping the garbage produced during selling. However, some traders clean up their waste by simply collecting it in its place and not throwing it into the trash or TPS. They left the garbage until the cleaners cleaned it up. As stated by the following informant:

"Clean up, yes, the garbage is swept away. Then it is collected, later someone will clean it themselves."

(Trader 1)

"If I sweep myself like this, it looks like there is garbage being swept away. Later if you don't sweep it yourself, and the officers don't sweep it, it looks dirty hahaha."

(Trader 3)

\subsubsection{Waste Reduction and Reuse Efforts}

In general, traders in Kamulan Market do not reuse the waste they produce because they no longer have any benefits and throw away the remaining waste from selling. However, some traders who sell fruit and vegetables reuse the remaining waste from selling them and use them as animal feed. They use the remaining waste from selling as animal feed because the waste they produce is organic waste. The type of waste generated affects the reuse of waste. In addition, before the organic waste is brought home for animal feed, if the food is good, it will be sold to those in need. As stated by the following informant:

“....some are thrown away, some are made to eat animals if someone buys it. The leftovers are pretty good for eating goats, eating chickens, eating animals. Someone bought the main thing."

(Trader 1)

"It depends on the garbage, if the bananas are thrown away, rotten bananas are sometimes thrown away, sometimes they are taken home. Broken bananas can be used to eat birds, banana peels to eat goats. I put a crackle bag like this, sis, if you can use it."

(Trader 3)

\subsubsection{Cleaning Fees}

The role of traders is indirectly carried out by paying cleaning fees. Traders who sell at Kamulan Market are charged a cleaning fee of Rp. 2000 for market cleanliness. Traders pay a fee of Rp. 2000 to the marketing officer. Then, the salary officer gave a ticket as proof that the merchant had paid the dues that day. As stated by the following informant:

"There is. If you want to clean it, it's 2000 a day, that's the ticket. Tickets for cleaning...."

(Trader 2)

"Yes, pay 2000. Every day the market officer is asked.

Those who ask there are 4 people taking turns....")

(Trader 4)

\section{DISCUSSION}

\subsection{Waste Management System at Kamulan Market}

The government has issued Law of the Republic of Indonesia Number 18 of 2008 concerning Waste Management [9]. The purpose and principle of the establishment of the law is to emphasize that waste management must be carried out based on the principles of responsibility, justice, awareness, security, togetherness, sustainability, safety, and economic value [14]. Waste management activities are also further explained in the Government Regulation of the Republic of Indonesia Number 81 of 2012 concerning Management of Household Waste and Household-like Waste [13]. The waste management system does not only concern waste management activities, but also relates to management, policies and regulations, infrastructure, user fees, and existing information and advice. The waste management system is also carried out at the Kamulan Market.

Waste management at Kamulan Market has been going well. Management is a science and an art, which consists of planning, organizing, directing, and supervising the performance of the organization by using its resources to achieve the goals and objectives of the organization [15]. Waste management aims to increase the usability and efficiency of waste management carried out at Kamulan Market. Based on the data obtained from research results to facilitate market waste management activities, Kamulan Market is equipped by 5 market managers. The task of the market manager is to ensure that the market system runs well, especially waste management, and also acts as a salary and collects market retribution. In addition to the market manager at Kamulan Market, there are also three cleaners who are responsible for the cleanliness of the market and the sweeping pesavon in the Kamulan Market environment and traders.

Regulations regarding waste management and hygiene at Kamulan Market are still not running optimally. However, the market manager and the janitor as the person in charge of cleanliness have given advice and campaigned for traders to always keep the market clean and always clean up the waste generated, although not in written form. Due to the absence of written 
regulations, there is no authority to impose sanctions on traders who take actions to dispose of waste carelessly or other deviant activities.

The results showed that the overall waste management activities carried out in Kamulan Market were not in accordance with the provisions contained in the Law of the Republic of Indonesia Number 18 of 2008 and Government Regulation of the Republic of Indonesia Number 81 of 2012 [9], [13]. Of the six waste management activities carried out at the Kamulan Market The discrepancy lies in the activities of waste sorting and waste processing. In waste sorting activities, Kamulan Market is not provided with separate trash bins for organic and inorganic waste, making it difficult for the cleaning staff to carry out their duties. In addition, the mixing of organic and inorganic waste can cause new problems such as organic waste that is difficult to decompose. Meanwhile, in waste processing activities, at Kamulan Market, waste processing is not carried out such as the manufacture of fertilizers, bio gas, and power plants. Organic waste that can no longer be used will be directly disposed of in landfills and inorganic waste that can be sold will be sold.

Waste management infrastructure is a tool and materials and supports used in waste management. The purpose of the infrastructure is to get the expected results according to the plan. At Kamulan Market related to waste management, facilities in the form of cleaning tools such as brooms, cikrak, trash cans, hoes, and sickles have been provided. In addition to cleaning equipment, the Kamulan Market also provides waste transportation equipment in the form of garbage carts and 3-wheel motors. Meanwhile, the waste management infrastructure provided by the market is the location of TPS and market buildings. Inadequate infrastructure could be one of the causes of the lack of cleanliness in the market. In Kamulan Market itself, the waste management facilities provided are sufficient [16]. In addition, trash cans have been provided at several market locations specifically for traders, but the trash cans are not given to each trader because the number is so minimal. The trash can is placed somewhere, so that one trash can is used by several traders.

Cleanliness levies are levies made by officers to the public for the services of providing waste management and cleaning services in a place. In Kamulan Market, there is also a levy for traders who sell. The basis of the collection refers to the Trenggalek Regency Regional Regulation Number 5 of 2012 concerning Market Service Retribution [17]. All traders who sell at Kamulan Market are required to pay a levy fee of Rp. 2000 for tax and market cleaning purposes, such as buying cleaning equipment, paying pesafon salaries, and others.

Based on data from interviews and observations of researchers as well as documentation conducted at Kamulan Market, it is known that market managers and cleaners have given an appeal to market traders to always keep the market clean. As well as traders who are given an appeal, they also have understood the information that has been provided and carried out with full responsibility. However, it is undeniable that there are still traders who do not keep their selling environment clean, they just leave their trash without cleaning the place of sale. They assume that it is the duty of the cleaners because they have paid the cleaning fee.

\subsection{The Behavior and Role of Kamulan Market Traders in Waste Management}

To create a clean, healthy, and comfortable market environment, it is not only seen from the waste management system, but also the behavior and participation of market residents in waste management. One of the obstacles to waste management efforts is the low level of community participation. Such a thing, of course, can also hinder the achievement of the objectives of waste management in the market because the participation of market traders plays an important role in the market development process proses [18]. The role or participation of the community in waste management activities is mostly influenced by the socio-cultural character because waste management activities are closely related to the mindset and behavior of the community in treating waste [19].

The role of traders in market waste management can be realized in the form of direct or indirect involvement. Direct involvement such as traders providing trash cans at selling locations, traders maintaining cleanliness, efforts to reuse waste, while indirect involvement with traders paying retribution fees for market cleanliness.

In general, garbage will be placed somewhere before being disposed of. In Kamulan Market, neither the market manager nor the cleaners provide trash cans for each trader. Trash cans are only provided in certain places for some traders. So traders must provide their own trash cans before the waste is disposed of in the provided trash cans. Most of the traders in Kamulan Market do not have a special trash can. However, they have temporary and makeshift trash cans to store the waste before it is disposed of. Traders store their waste temporarily without being separated into plastic bags/cracks, buckets/dippers, fruit baskets/fruit boxes.

In general, traders collect the waste left from selling without separating the waste by type. Fruit and vegetable traders at Pasar Giwangan Yogyakarta have the attitude of not segregating waste such as leftover rotten vegetables and fruit, plastic and sacks put together in front of the merchant's kiosk [20]. At the Traditional Lasi Market, Canduang District, Agam Regency, that there are still many traders who have not collected waste separately between organic and inorganic waste, the waste is combined in one place and then disposed of [21]. 
It is the duty of traders as business actors to always maintain the cleanliness of the selling location and create a clean and comfortable market location. Traders need to know and understand the concept of waste management properly so that the cleanliness of the market is maintained. Gunungpati Market traders have high environmental awareness behavior, this can be seen from the traders who always neatly organize their merchandise and keep the environment clean in the area where they sell, such as sweeping and throwing garbage in its place [22]. At Pasar Aur Kuning, Bukittinggi City, traders do not have a regular time to clean their trading locations, when there is new time they will clean up [23]. The reason is because they are more concerned with tidying up their wares and serving buyers than the cleanliness of the surrounding environment. The same thing also happened in Wonodri Market, the behavior of traders related to waste management in Wonodri Market was still less than perfect, indicated by the pile of garbage in the aisle of the kiosk [24].

The results of this study indicate that the efforts made by traders at Kamulan Market to maintain cleanliness are that traders collect the remaining waste from selling, besides that they also clean the place of sale by sweeping the garbage produced during selling. However, some traders clean up their waste by simply collecting it in its place and not throwing it into the trash or TPS. They left the garbage until the cleaners cleaned it up.

Regarding efforts to reuse waste, in general, traders who sell fruit and vegetables reuse the remaining waste from selling by using it as animal feed. They use the remaining waste from selling as animal feed because the waste they produce is organic waste. The type of waste generated affects the reuse of waste. In addition, before the organic waste is brought home for animal feed, if the food is good, it will be sold to those in need. Vegetable waste produced by the market can be used as ruminant feed, because of its abundant availability and has economic value because the price is cheap and does not compete with human needs [25]. By making animal feed, vegetable waste produced by traders will increase the added value obtained while at the same time being able to solve environmental pollution and overcome the shortage of animal feed [26].

In the process, all traders are required to pay a levy for market cleanliness. Traders say that the fee that must be paid is Rp. 2000 per day. The fee is paid based on the place used for selling. There is no coercion and sanctions, but the payment is the awareness of every trader. So that in the process of withdrawing the dues there are no traders who do not pay. So far, traders have carried out their obligations as market residents by paying dues to market managers as their responsibility to maintain cleanliness.

\section{CONCLUSION}

The waste management system at Kamulan Market for cleanliness is managed by a janitor who is directly supervised by the market coordinator. Regulations regarding waste management and market hygiene are still not running optimally. The behavior and role of traders in managing waste directly is by providing temporary waste shelters such as plastic bags/cracks, buckets/dippers, fruit baskets/fruit boxes. Meanwhile, the role of traders is indirectly carried out by paying cleaning fees. The government, market managers, cleaners, and market traders can cooperate to create an orderly, clean, and comfortable market. With the existence of waste processing activities, it is expected to increase the added value obtained as well as to solve environmental pollution problems and increase income.

\section{AUTHORS' CONTRIBUTIONS}

AW: concept and design the study, data collection, data analysis, writing the manuscript; $\mathrm{S} \& \mathrm{AK}$ : validation, writing, supervision.

\section{ACKNOWLEDGMENTS}

The authors thank to Faculty of Sport Science, Universitas Negeri Malang that support this study. The authors also would like to express the gratitude to all informants.

\section{REFERENCES}

[1] Sejati, K. (2009). Pengolahan Sampah Terpadu: Dengan Sistem Node, Sub Point, Center Point. Penerbit Kanisius.

[2] Herawati, C., Kristanti, I., Selviana, M., \& Novita T. (2019). Peran Promosi Kesehatan Terhadap Perbaikan Pengetahuan, Sikap, Dan Perilaku Membuang Sampah Pada Siswa Sekolah Menengah Atas. Dimasejati: Jurnal Pengabdian Kepada Masyarakat, 1(1), 40-51.

[3] Ikhtiar, M. (2017). Pengantar Kesehatan Lingkungan. CV. Social Politic Genius.

[4] Putri, Y. P. (2015). Keanekaragaman Spesies Lalat (Diptera) dan Bakteri pada Tubuh Lalat di Tempat Pembuangan Akhir Sampah (TPA) dan Pasar. Jurnal Dampak, 12(2), 79-89.

[5] Andriani, T. (2017). Peran Pedagang dalam Pengelolaan Sampah di Lingkungan Pasar Ciputat. Skripsi S1 Fakultas Ilmu Tarbiyah dan Keguruan UIN Syari Hidayatullah Jakarta 2018 , 195.

[6] Rachman, A. (2011). Gambaran Pengelolaan Sampah Di Pasar Sentral Sungguminasa Kecamatan Somba Opu Kabupaten Goa. Skripsi 
Program Studi Kesehatan Masyarakat Fakultas Ilmu Kesehatan Universitas Islam Negeri Alaudin Makassar, 96.

[7] Djafar, J., Ainun, S., \& Dirgawati, M. (2014). Identifikasi Timbulan Sampah di Pasar Induk Caringin Bandung. Reka Lingkungan: Jurnal Institusi Teknologi Nasional, 1(2), 1-9.

[8] Mentari, Suasti, Y., \& Syahar, F. (2018). Partisipasi Pedagang Kaki Lima Dalam Pengelolaan Sampah di Pasar Bawah Kota Bukittinggi. Jurnal Buana, 2(4), 328-337.

[9] Undang-undang Republik Indonesia Nomor 18 Tahun 2008 Tentang Pengelolaan Sampah.

[10] Anggito, A., \& Setiawan, J. (2018). Metodologi Penelitian Kualitatif. CV Jejak.

[11] Gora, R. (2019). Riset Kualitatif Public Relations. CV. Jakad Publishing Surabaya 2019.

[12] Peraturan Daerah Kabupaten Trenggalek Nomor 27 Tahun 2016 Tentang Pengelolaan Sampah.

[13] Peraturan Pemerintah Republik Indonesia Nomor 81 Tahun 2012 Tentang Pengelolaan Sampah Rumah Tangga dan Sampah Sejenis Sampah Rumah Tangga.

[14] Suryaningsih, T. (2019). Implementasi Undangundang Nomor 18 Tahun 2008 Tentang Pengelolaan Sampah dalam Rangka Kerjasama dan Kemitraan Pengelolaan Sampah di Dinas Lingkungan Hidup Kota Binjai. Skripsi Program Studi Ilmu Administrasi Publik Fakultas Ilmu Sosial Dan Ilmu Politik Universitas Muhammadiyah Sumatera Utara Medan 2019, 82.

[15] Wijayanto, D. (2012). Pengantar Manajemen (1st ed.). PT Gramedia Pustaka Utama.

[16] Widodo, T. (2013). Studi Tentang Peranan Unit Pasar Dalam Pengelolaan Sampah di Pasar Merdeka Kota Samarinda. Jurnal Administrasi Negara, 1(1), 1-7.

[17] Peraturan Daerah Kabupaten Trenggalek Nomor 5 Tahun 2012 Tentang Retribusi Pelayanan Pasar.

[18] Setiawan, I. (2017). PEengelolaan Sampah Pada Dinas Pasar Kebersihan dan tata Kota kabupaten Hulu Sungai Utara. As Siyasah, 2(2), 15.

[19] Puspitawati, Y., \& Rahdriawan, M. (2012). Kajian Pengelolaan Sampah Berbasis Masyarakat dengan Konsep 3R (Reduce, Reuse, Recycle) di Kelurahan Larangan Kota Cirebon. Jurnal Pembangunan Wilayah \& Kota, 8(4), 349-359.

[20] Safitri, M. E., Rangkuti, A. F., Soepomo, J. D., \& Warungboto, J. (2019). Hubungan Tingkat Pendidikan, Pengetahuan, dan Sikap dengan Perilaku Pengelolaan Sampah pada Pedagang
Buah dan Sayur di Pasar Giwangan Yogyakarta. Thesis Unad, 14.

[21] Fatma, F. (2019). Analisis Pengelolaan Sampah Organik Pasar Lasi Tradisional di Kecamatan Canduang Kabupaten Agam Menara. Ilmu, 8(2), 60-69.

[22] Hidayah, D. N. (2015). Pengaruh Tingkat Pendidikan Pedagang Pasar Terhadap Perilaku Lingkungan Di Pasar Gunungpati Kecamatan Gunungpati Kota Semarang Tahun 2015. Skripsi S1 Pendidikan Geografi Jurusan Geografi Fakultas Ilmu Sosial Universitas Negeri Semarang Tahun 2015, 143.

[23] Anggraini, R., U, I., \& Chandra, D. (2018). Partisipasi Pedagang Dalam Menjaga kebersihan Lingkungan Pasar aur Kuning Kota Bukittinggi. Jurnal Buana. 2(5), 441.

[24] Wahyuni, R., Ap, P., \& Purnaweni, H. (2019). Behavior Analysis of Traders Regarding Waste Management In The Wonodri Market In Semarang. E3S Web of Conferences, 125, 09015.

[25] Wolayan, F. R., Tulung, Y. R. L., Bagau, B., Liwe, H., \& Untu, I. M. (2019). Silase Limbah Organik Pasar Sebagai Pakan Alternatif ternak Ruminansia (Sebuah Review). Pastura, 7(1), 52.

[26] Bahrun, B., \& Herliana, O. (2019). Pemanfaatan Limbah Pasar Sebagai Pakan pada Kelompok Ternak dan Diversifikasi Produk Olahan Entok Guna Meningkatkan Pendapatan Masyarakat Desa Wanadadi Banjarnegara. Jurnal Pengabdian kepada Masyarakat, 3(1), 7 